\title{
The unrealised ethical potential of the Methodist theology of prevenient grace
}

\begin{tabular}{|c|c|}
\hline $\begin{array}{l}\text { Author: } \\
\text { David N. Fielo }\end{array}$ & \\
\hline $\begin{array}{l}\text { Affiliations: } \\
{ }^{1} \text { Methodist e- } \\
\text { Switzerland }\end{array}$ & Academy, Basel, \\
\hline $\begin{array}{l}{ }^{2} \text { Research Ins } \\
\text { Theology and } \\
\text { University of } \\
\text { South Africa }\end{array}$ & $\begin{array}{l}\text { itute for } \\
\text { Religion, } \\
\text { south Africa, }\end{array}$ \\
\hline $\begin{array}{l}\text { Note: } \\
\text { Dr David Fielo } \\
\text { associate in th } \\
\text { Theology and } \\
\text { University of } \\
\text { South Africa. }\end{array}$ & $\begin{array}{l}\text { is a research } \\
\text { le Institute for } \\
\text { Religion, at the } \\
\text { South Africa, }\end{array}$ \\
\hline $\begin{array}{l}\text { Corresponde } \\
\text { David Field }\end{array}$ & ce to: \\
\hline $\begin{array}{l}\text { Email: } \\
\text { david.field@s }\end{array}$ & unrise.ch \\
\hline $\begin{array}{l}\text { Postal addres } \\
\text { Augustinerga } \\
\text { Basel, Switzer }\end{array}$ & $\begin{array}{l}\text { s: } \\
\text { se 11, } 4051 \\
\text { land }\end{array}$ \\
\hline $\begin{array}{l}\text { Dates: } \\
\text { Received: } 01 \\
\text { Accepted: } 21 \\
\text { Published: } 14\end{array}$ & $\begin{array}{l}\text { Apr. } 2015 \\
\text { June } 2015 \\
\text { Oct. } 2015\end{array}$ \\
\hline $\begin{array}{l}\text { How to cite } \mathbf{t} \\
\text { Field, D.N., } 20 \\
\text { unrealised etl } \\
\text { of the Metho } \\
\text { of prevenient } \\
\text { HTS Teologies } \\
\text { Theological S } \\
\text { Art. \#2987, } 8 \\
\text { dx.doi.org/10 } \\
\text { v71i1.2987 }\end{array}$ & $\begin{array}{l}\text { lis article: } \\
15, \text { 'The } \\
\text { hical potential } \\
\text { dist theology } \\
\text { grace', } \\
\text { e Studies/ } \\
\text { udies } 71(1) \text {, } \\
\text { pages. http:// } \\
4102 / \text { hts. }\end{array}$ \\
\hline $\begin{array}{l}\text { Copyright: } \\
\text { (C) 2015. The } \\
\text { Licensee: AOS } \\
\text { OpenJournals } \\
\text { licensed unde } \\
\text { Commons Att } \\
\text { License. }\end{array}$ & $\begin{array}{l}\text { Authors. } \\
\text { IS } \\
\text { This work is } \\
r \text { the Creative } \\
\text { ribution }\end{array}$ \\
\hline Read online: & \\
\hline 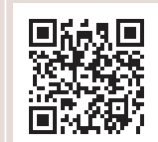 & $\begin{array}{l}\text { Scan this QR } \\
\text { code with your } \\
\text { smart phone or } \\
\text { mobile device } \\
\text { to read online. }\end{array}$ \\
\hline
\end{tabular}

This article examines the unrealised ethical potential of the theology of prevenient grace. It begins with a brief analysis of John Wesley's rejection of slavery as rooted in his theology of prevenient grace. This is demonstrated in the next section which analyses Wesley's notion of prevenient grace. This is followed by a constructive proposal for a contemporary theology of prevenient grace and some ethical implications of this theology, for contemporary social and political ethics, are developed.

\section{Introduction}

In 1774 John Wesley, the principle founder of Methodism, compiled a small booklet entitled Thoughts upon Slavery (Wesley 1979:59-79). Like some of his other writings he drew extensively from the work of others. However, he selected passages, carefully edited them, and added arguments of his own making the final product a short but powerful argument against slavery which expresses Wesley's own theology (see Brendlinger 2006). A careful reading of this booklet reveals some interesting but often neglected aspects of Wesley's thought.

Firstly, the booklet provided a description of African societies before the advent of slavery based on the testimonies of earlier European explorers. He described them as societies which were characterised by justice, morality and mercy, in striking contrast to the Christianised European societies of his day.

Secondly, he ascribed this ethos of justice, morality and mercy in part to the worship of God being central to these societies. This was, of course, not Christian worship but either Islamic or traditional African worship. He contrasted this with the extreme cruelty that the African people suffered through enslavement at the hands of those who professed to be Christians.

Thirdly, having described slavery against the background of earlier African societies he proceeded to develop an ethical argument. He started his argument by stating that he would be setting the Bible aside. This was a remarkable step, as biblical texts were regularly quoted by both opponents and supporters of slavery and were used in some of the sources that Wesley used for his booklet. ${ }^{1}$

Fourthly, his ethical argument was based on the propositions that all people have natural liberty; that natural justice required that natural liberty be respected, and that mercy required that the cruel treatment of people be stopped.

Fifthly, he ignored the argument that whilst the slave trade might be cruel when the slaves were brought to America they had an opportunity to hear the gospel. For Wesley it would have been better if they had been allowed to remain in their own countries.

These arguments are contrary to many popular images of Wesley as a revival preacher who declared that the world was his parish, who spent himself in preaching the gospel, who insisted on the necessity of people being born again, and who claimed to be a man of one book - the Bible. Here he affirmed other religions, ignored the Bible and suggested that African's would have been better off had they not encountered Europeans.

However, a deeper engagement with Wesley's writings suggests to the contrary that his argument was deeply rooted in his theology and ought to be viewed as typically Methodist as a concern to preach the gospel and call people to a life of holiness. Underlying the unexpected arguments is Wesley's theology of prevenient grace. Within Methodism the significance of this theological 1.Biblical arguments can be found in the following sources used by Wesley: Anthony Benezet, Some historical account of Guinea
(Brendlinger 2007:137-204), Benezet, A short account of the part of Africa inhabited by the Negros, (Brendlinger 2007:123-135; Sharp 1764). 
theme has often been limited to the sphere of personal salvation and its broader theological contribution has been neglected and allowed to atrophy.

The broader significance of the theology of prevenient grace was suggested by the nineteenth century British Methodist theologian William Burt Pope who proposed that the theology of prevenient grace 'lights up the whole sphere of ethics' (Pope 1880:158). However Pope himself did not develop this insight in any detail. ${ }^{2}$ Over a century later the Argentinean Methodist José Míguez Bonino argued that Wesley and Pope's theology of prevenient grace provided significant resources for developing a theological response to the challenges articulated by Liberation Theologies from within the Methodist tradition in Latin America. He made a number of suggestive proposals about how this could be developed (see Miguez Bonino 1998, 2000). However, like Pope's proposal, Míguez' argument did not stimulate any major attempt to interpret the ethical significance of prevenient grace.

\section{Prevenient grace in the theology of John Wesley}

John Wesley developed his theology of prevenient grace within the context of his rather heated debate with his Calvinist contemporaries. Wesley, along with Calvinistic theology, strongly affirmed human sinfulness and the inability and unwillingness of human beings, in their natural state, to seek God. If anything his description of human sin is more pessimistic than Calvin's. ${ }^{3}$ However he rejected the Calvinist solution that God chose some human beings to be saved and then through a special intervention of God's grace called these and only these out of sin, enabling them to repent and believe. Wesley argued that God loved all human beings; that Christ had died for the salvation of all, and God would not hold people responsible for not doing what they were incapable of doing. Wesley's counter proposal was to affirm that all human beings were bound in sin, and that God is free and sovereign and always assumes the initiative in God's interaction with humanity. But he added that, as an outworking of the Christ's atoning death for all human beings, the Spirit of God was present and active in all people creating within them the ability to respond to God. Whilst human beings are called to respond to God's grace this response is not predetermined by God and as a consequence of this grace human beings are able to reject or accept God's action in their lives. It is this universal work of the Spirit that Wesley described as prevenient or preventing grace. ${ }^{4}$

Wesley did not provide us with a systematic account of his understanding of prevenient grace; rather he left scattered references throughout his writings. However, what is

2.Prevenient grace is an integral element in Popes systematic theology and references can be found throughout his A Compendium of Christian Theology (Pope 1880); for an analysis of Pope's theology see Field (2015).

3.Wesley argued this in The doctrine of original sin: According to scripture, reason and experience (Wesley 2012:117-481).

4.Wesley wrote numerous responses to Calvinism (see Wesley 2013) clear is that prevenient grace became his prime category for interpreting the work of God beyond the church. ${ }^{5}$ In comparison to other Protestant traditions it, thus, had a similar function to the kingdom of the left hand in Luther's two kingdoms theology and common grace in Reformed theology. ${ }^{6}$ There are also interesting resonances with Roman Catholic theologies that emerged under the influence of Karl Rahner and the Second Vatican Council. ${ }^{7}$ For Wesley all of human society is characterised by the interaction between sin and prevenient grace. In addition to the explicit references to prevenient grace Wesley refers to other gracious gifts of God to humanity without specifically relating them to prevenient grace.

For the purpose of this article I will describe a number of aspects of Wesley's theology of prevenient grace which have particular theological and ethical significance (Collins 2007:72-82; Crofford 2010; Maddox 1994:83-93; Rogers 1967; Shelton 2014):

1. Grace in Wesley's theology of prevenient grace is the active presence of the Spirit of God within all human beings. As such, grace is inherently relational and dynamic. The active presence of the Spirit enables and calls for human beings to respond to God's revelation and action, to the extent that a person responds to the Spirit, and the Spirit works. Positive responses to the work of the Spirit intensify the Spirit's active presence. Negative responses can lead to the withdrawal of the Spirit's presence.

2. The Spirit is actively present in all human beings regardless of religion or culture as a universal outworking of the death of Christ. This universal presence of the Spirit liberates fallen human beings from some of the consequences of $\sin$ and, thus, gives them a measure of free will and in so doing enables human moral responsibility. No human being is totally depraved unless she or he consistently rejects the work of the Spirit.

3. As a consequence of the presence of the Spirit all human beings have a sense of right and wrong, a standard by which they evaluate their behaviour and an awareness of having conformed to or departed from this standard. Wesley does not provide any detailed explanation of how the Spirit does this. Hence, the phenomenon of human conscience is a consequence of prevenient grace. The standard by which they can evaluate right and wrong is the moral law of God. For Wesley the moral law is the manifestation to creatures of the moral character,

5.Most secondary literature has focused on the role of prevenient grace in his understanding of the ordo salutis (or better via salutis) in the context of his debate understanding of the ordo salutis (or better via salutis) in the context of his debate
with the Calvinists. Recent developments in Wesley studies have opened the way for a more comprehensive interpretation of prevenient grace in Wesley's theology these include a greater awareness of the redemptive historical framework of Wesley's theology (see Rodes 2013); the recognition that in Wesley's later work personal salvation was put in the context of the eschatological hope for renewal of the whole creation (see Runyon 1998) and a renewed interest in Wesley's pneumatology (see Klaiber 2013).

6.Various Christian traditions have affirmed, described and defined that God's work beyond the church has been in different ways since the writings of the early church fathers. Dupuis (2001.53-83) provides important examples of this amongst the fathers. Dupuis (2001:53-83) provides important examples of this amongst the early church fathers. Theological sources and precedents for Wesley's theology of prevenient grace can be found in a variety of patristic and medieval thinkers as well as early Anglicans and Quakers (see Rogers 1967:25-58 and Crofford 2010:19-66). tradition in dialogue with patristic, medieval and reformation thinkers (1993:61-91).

7.Knitter provides a useful summary of these views (2002:63-99). 
inscribed deep within the human person at creation, lost in the fall and re-inscribed through prevenient grace. The basic principles of the moral law in relation to our fellow human beings are summed up in the triad of justice, mercy and truth and more intensely in the golden rule. This is the natural law to which he appeals in his condemnation of slavery. ${ }^{8}$

4. The Spirit empowers all people to act, to some varying degrees, in accordance with the moral law. The extent to which this is observed in a given society or person is a consequence of that person or society responding to the active presence of the Spirit. In various writings Wesley noted that the moral triad of justice, mercy and truth could be found in a variety of non-Christian societies often to a greater extent than within the 'Christian' societies of Europe.

5. The presence of the Spirit leads to a desire within human beings for a relationship with God. God accepts and shows favour to all who seek God regardless of whether or not they have heard the gospel. Hence, other religions can be a means of God's grace. ${ }^{9}$ Wesley could argue, for example, that Socrates was moved by the Holy Spirit to promote religious change in Athen ${ }^{10}$ and, as we noted above, he related the morality and justice of African societies to their worship of God in an Islamic or African Traditional context.

6. Wesley's understanding of prevenient grace should be seen in the context of his understanding of redemptive history. Wesley developed a modified version of classic reformed federal theology. ${ }^{11}$ In his understanding, God initiated a covenant of grace with all people in the aftermath of the fall. Wesley understood that within the covenant of grace there were different dispensations, God's grace is present in each dispensation but what God requires from people under specific dispensations is different. The dispensation of the heathen is inaugurated in the aftermath of the fall and encompasses all human beings. Under this dispensation God requires that people fear God and obey the basic moral principles of natural law. Those who do this are accepted by God. God's revelation to Moses introduced a new dispensation in which God's requirements were set out in the law. In Christ God inaugurates the dispensation of the kingdom of God's grace. Whilst these dispensations occur in a redemptive historical sequence the change from one dispensation does not abolish or negate the earlier dispensation. People can relate to God existentially in a previous covenant although it has been succeeded by

8.While Wesley does not discuss how his understanding of natural law relates to other theories Kenneth Collins argues that it has an affinity with Thomas Aquinas's theological and teleological understanding rather than with the understandings that were being developed by enlightenment thinkers (Collins 2007:270-277).

9.In his sermon 'On Divine Providence' He states: 'Is he the God of the Christians, and not of the Mahometans and heathens also? Yea, doubtless of the Mahometans and heathens also. His love is not confined: The Lord is loving unto every man, and his mercy is over all his works. He careth for the very outcasts of men: it may truly be said, Free as the air thy bounty streams. O'er all thy works: thy mercies' beams. Diffusive as thy sun's arise' (Wesley 1985:542)

10.See his comments on Acts 4:19 and 17:23 (Wesley 1976:407 \& 465).

11.Reformed federal theology is not the only tradition to draw on the biblical motif of the covenant to describe the history of God's salvific interaction with creation. For a Roman Catholic interpretation see Murray (1992). another. Hence, people who had never heard the gospel relate to God under the dispensation of the heathen and are accepted by God under the conditions of this dispensation. Jews continued to relate to God under the dispensation of Moses. This is also true of people who have had varying degrees of contact with Christianity (see Rodes 2013). In this framework the Spirit's active presence is universal but with different intensity. In this way Wesley can affirm God's acceptance of all people and at the same time affirm a unique place for the gospel of Christ.

7. The coming of Christ inaugurates the kingdom of God in the form of the kingdom of grace which is present as a structured community of people within whom God reigns - this is the church. ${ }^{12}$ Wesley envisaged the kingdom of grace growing and transforming all aspects of human society. At the parousia the kingdom of grace would be consummated by being transformed into the kingdom of glory which is the renewal of all creation. Prevenient grace, within this redemptive historical scheme, functions to prepare for and anticipate this transformation of human society.

8. Closely related to his understanding of prevenient grace, Wesley argued that human reason is a gift of God given to all human beings. Whilst Wesley does not explicitly relate it to prevenient grace, the presence of reason is an essential aspect of the functioning of human conscience and the application of the moral law to particular issues. ${ }^{13}$ As such it can be considered to be an element of prevenient grace.

9. Wesley argued that the development of civil liberty was a gift of God. Whilst he did not develop this in detail he viewed all human beings as possessing natural liberty as a consequence of their religious responsibility before God, enabled by prevenient grace. No human being had the right to deprive another human being of his or her liberty. The development of various civil liberties is the outworking of this natural liberty within particular societies. Wesley was aware that this emergence of political civil liberty was the consequence of complex historical processes. ${ }^{14} \mathrm{He}$ did not systematically relate this to prevenient grace but his understanding of these developments coheres with his theology of prevenient grace. A particularly relevant example of this is the development of religious freedom in the eighteenth

12. Wesley's ecclesiology has been described by Albert Outler as 'an unstable blend of Anglican and Anabaptist ecclesiologies'. (Introduction to Wesley's sermon 'Of the Church' in Wesley 1986:46). Wesley's mature understanding of the church was focused on the church as the visible company of genuine believers. Institutional focused on the church as the visible company of genuine believers. Institutional
structures were important and Wesley believed some but not all aspects of structures were important and Wesley believed some but not all aspects of
these structures had divine authorisation. The purpose of these structures was the development of a community of holy people. As such he argued that many aspects of church order were practical responses to particular issues and contexts they could and should be changed in different circumstances. Wesley placed a great emphasis on the sacraments, arguing for the importance of regular - at least weekly - participation in Holy Communion and, despite Outler's comments, for infant baptism. His focus of his baptismal theology was more on individual salvation, he believed that through baptism the infant was regenerated but that in the vast majority of cases children lost the grace bestowed at baptism as a result of their sin (see Borgen 1972).

13.See his sermon 'The case of reason impartially considered' (Wesley 1985 587-600).

14. He documented this in his, A concise history of England from the earliest times to George the II in four volumes (Wesley 1775). 
century. Wesley argued that God was at work in these political processes, although he recognised that it did not have substantial support from the followers of mainstream Christianity but was rather promoted by Deists and others who rejected orthodox Christianity. Further, this development of greater religious freedom, amongst other things, created space for the evangelical revival. ${ }^{15}$ God's work in and through non-believers inspiring their desire for civil liberty prepared the way for the proclamation of the gospel.

10. In various places Wesley ascribes aspects of the development of human knowledge as gifts from God. ${ }^{16}$ He proposed that the discovery of various natural medicines was also a consequence of the work of the Spirit (see Wesley 2007:v-vi). Yet again in both these cases he was aware of the complex processes of acquiring knowledge.

The method that Wesley adopted to argue against slavery was, thus, consistent with his understanding of prevenient grace. As God had given all human beings awareness of justice, mercy and truth there was no necessity to appeal explicitly to the Bible in making an ethical argument; he could appeal to the general public using concepts such as natural law and liberty. He was able to argue that the natural law inscribed in the life of all people had greater authority than positive law. He could expect that that people who made no claim to be Christians would respond to his appeal. He could affirm the goodness of the African cultures from which the slaves were uprooted as the consequence of prevenient grace and their Islamic or traditional worship of God could also be affirmed as a means of encountering God. He could ignore the argument that whilst slavery was evil the slaves benefited because they came into contact with the Christian gospel.

However, an approach to ethics rooted in prevenient grace did not become a significant feature of Methodist ethics and the ethical potential of the theology of prevenient grace was neglected. As a consequence Methodist ethicists often appeal to a range of other theological ethical frameworks in addressing ethical issues, such as the relationship between church and state, human rights, xenophobia and corruption.

\section{Aspects of a theology of prevenient grace for the 21st century}

Whilst Wesley developed his understanding of prevenient grace in the context of particular eighteenth century theological debates, its potential significance is not restricted to these debates. As an attempt to describe the mystery of God's working in the world beyond the church, it has latent possibilities for the development of a contemporary social and public theology in the context of pluralistic and secular 15.See his sermon 'On former things' (Wesley 1986:442-453). 16.See his preface to $A$ survey of the wisdom of god in creation or a compendium of natural philosophy in Wesley 1979, vol. 14:300-303 and his sermon 'On forme things' (Wesley 1986:442-453). societies such as South Africa. Prevenient grace provides the theological foundations for working with people of different faiths as well as those who are not members of any religious tradition in the common struggle for justice, compassion and integrity. However, the unfolding of these possibilities is dependent upon a critical and creative reworking of Wesley's theology to develop a more systematic and inclusive account of God's work in the world beyond the church. What follows is not a comprehensive exposition of such a theology but rather the identification of key components that should be included in a contemporary account of prevenient grace.

Presupposed in a theology of prevenient grace is a reciprocal understanding of God's grace. In the Wesleyan tradition grace is the personal presence of the Spirit of God amongst and within human beings as the one who heals, transforms and empowers. Because it is the personal presence of God it is interactive and dynamic. God acts to enable human beings to respond to God who, in turn, responds to their response. Whilst God in love and grace is persistent in seeking to draw people to Godself, overcome sin and absorb human rejection; because God respects human freedom persistent negative responses can result in the withdrawal of the influence of God's grace. God might in sovereign freedom and love continue to engage human beings who respond negatively; when they react positively God intensifies God's presence and power. Wesley's theology is here not entirely coherent in this respect - he attempts to bring together the affirmation of the reality of human liberty, God's persistent love, the reciprocal character of the relationship between grace and humanity and, at the same time, to hold up the possibility of God acting in surprising, new and unprecedented ways to respond even to the most resistant sinner. In the end he is confronted with the mystery of God which cannot be reduced to neat theological schemes.

God's grace does not act in competition with human agency but is the ground of agency. It liberates, empowers and enables human beings to act. Grace is, thus, present within the normal course of human history and is not distinguished by its supernatural extravagance, but by the emergence, divergence and convergence of dynamics in the human person and human societies which conform to the character and purpose of God portrayed in the biblical witness.

Whilst God's grace is a comprehensive concept, in this context it refers particularly to God's response to the human predicament. That is the human beings multidimensional failure to and inability to fulfil God's purpose for them to reflect God's character and represent God's interests. This includes the traditional concept of sin and the universal bias to evil that pervades the human person, but moves beyond that to include the embeddedness of this bias in the structures of human society that has been emphasised by liberation theologies. Institutions, legal systems, economic systems, business enterprises and even religious organisations become structured to benefit the political and economic elite through the exploitation of the poor, the disempowered and 
the excluded. These structures develop an institutional life of their own that is more than the individual acts of the persons involved. They often include and benefit people who have not responsibly chosen to be part of these structures, but who are part of the elite (see Field 2003; Nolan 1988:31-48; De Gruchy 1991:150-156). Repressive cultural and social structures cause suffering and disempower their victims, leading to the deep personal woundedness that Minjung theologians have designated with the Korean concept of han. Like sin, han can become imbedded in human society and is, thus, passed from one generation to another (see Park 1993, 2004). Apartheid and its continuing effects on the life of South Africans provides illuminating illustration of structural sin. When it provided the legal structure of the land the system of apartheid ordered society for the benefit of the White minority (including those who opposed it) through the exploitation and oppression of the majority. This exploitation and oppression inflicted psychological as well as material suffering on people. The abolition of apartheid as a legal system did not remove its structural or psychological impact on the majority.

A Wesleyan concept of prevenient grace differs from the Reformed concept of common grace as it is always directed towards salvation. However in contrast to Wesley, a contemporary theology of prevenient grace will be shaped by an understanding of salvation as the coming of God's comprehensive eschatological reign. This is not to underplay the importance of personal salvation but is to view this as the proleptic manifestation of God's renewal of all things. The impact of prevenient grace is not to be identified with God's reign; it is rather the preparation for and anticipation of God's reign. The coming of God's reign is, however, an eschatological and unexpected event characterised by dynamic newness. Hence, there is no progressive development from the consequences of prevenient grace to the coming of God's reign and the theology of prevenient grace is not an ideology of progress. It is within this broader context of the Spirit's personal and active presence preparing the way for and anticipating the coming of God's reign that the Spirit is in a particular way present within the individual's life, drawing them to faith in Christ

Prevenient grace prepares for the coming of God's reign, firstly, by restoring human agency distorted and suppressed by $\sin$ and woundedness to enable human beings to participate in God's reign. Secondly, it is revelatory, bringing to people an awareness of God's moral law which Wesley summarises by the triad of justice, mercy and truth. Thirdly, it inspires hope for a new world where evil and suffering no longer spread their vicious influence over human life. Fourthly, the Spirit enters into the midst of human suffering, challenging and judging the maleficent structures of power and causing cracks and fractures to create spaces of hope in which healing and transformation can take place.

Prevenient grace anticipates God's reign by creating diverse and multifaceted foretastes of the kingdom that inspire people to long for more. The first foretaste is the empowerment of people to do good and to seek justice, mercy and truth. The second is that the Spirit is present amongst suffering humanity to bring healing to the wounded and the broken and empowering the disempowered.

Prevenient grace is the pervasive work of the Spirit in, with, through and under human persons, history, and societies regardless of people's religious beliefs or lack thereof. God's Spirit is present and active amongst and through the diversity of human religions, cultures and philosophies. However, prevenient grace is not a universal upgrade for all human beings. The presence of the Spirit within the complex dynamics of human persons and societies is personal, dynamic and interactive. As a consequence the outworking of prevenient grace is manifold and contextually shaped with different societies and cultures displaying dissimilar expressions of prevenient grace.

Persons and societies exist in the dialectic of human sin and prevenient grace. Within human existence in its manifold dimensions there is a constant, dynamic and interactive tension between sin and grace. Hence, the consequence of prevenient grace is always uneven and multifaceted displaying both progression and regression and often a complex mix of both. Because the work of the Spirit is interactive there is growth in justice, mercy and truth as the Spirit responds to those who promote these values. Yet because human depravity is always present there will be retrogression, failure and even radical reversals. Yet, because the work of the Spirit is personal, free and unpredictable there is always the potential for dramatic and unexpected movements towards justice, mercy and truth. Even in the midst of depravity the Spirit responds to, limits, overcomes and redirects the sinful intentions and evil consequences of human persons and social structures. The Spirit can and does bring good out of evil without legitimating the evil. Yet human sin often perverts and undermines the good consequences of the Spirit's work. In the South African context one can affirm the liberation struggle and the development of a constitutional democracy as an outworking of prevenient grace and yet recognise the abuses that have occurred in the post-apartheid era as a product of human sin.

\section{Aspects of an ethic rooted in a theology of prevenient grace}

The interpretation of prevenient grace as preparing for and anticipating the coming of God's reign contributes to the development of theological foundations for the development of a social ethic shaped by this aspect of Wesleyan theological heritage. Two caveats need to be noted in this regard. Firstly, a theology of prevenient grace is only one contribution to an adequate Wesleyan and Methodist social ethic. It needs to be complimented by developing two other aspects of the tradition; that is the theology of holiness and ecclesiology. Whilst such developments lie 
beyond the scope of this paper they are essential to an adequate account of a responsible Christian life in society. ${ }^{17}$ Secondly, the development of such a social ethic is not an exercise in denominational chauvinism or provincialism. It is rather directed on the one hand to assisting Methodists to engage their social context in a manner which is consistent with their heritage. On the other it is intended to contribute to ecumenical dialogue on the significance of the Christian faith in the 21st century. The potential contribution of such a theology will be illustrated by the description of selected aspects of such an ethic.

An ethic of prevenient grace is characterised by realism and hope. It is realistic because it recognises the limitations of human finitude and ignorance, as well as the power and pervasiveness of human sin and woundedness, discussed more fully above. Human beings and human social structures are not as evil as they could be but they have the potential for radical evil, such that even actions carried out with the best intentions can be influenced by sin and woundedness and may have evil consequence as a consequence of ignorance and mistakes. ${ }^{18}$ However, this realism stands in tension with an ethical optimism which affirms that the Spirit of God is present and at work in the midst of human depravity and woundedness. In the most hopeless and depraved situations the Spirit is present, more than that the Spirit is more particularly present amongst those who suffer, who are rejected and downtrodden. It is here that the Spirit groans with the suffering and works to heal, to transform and to empower them to become God's agents of change. An ethic of hope is never satisfied with the status quo but always works towards fuller expressions of justice, mercy and truth in society, even in the most hopeless situations, in prayerful expectation that the Spirit of God is present and at work. ${ }^{19}$ The combination of these two characteristics calls us to be involved in the complexity, brokenness and incompleteness of human society in order to bring about transformation.

An ethic rooted in prevenient grace recognises an important distinction between God's work in and through the church which is a present though partial manifestation of God's reign and God's work beyond the church in preparation for and anticipation of God's reign. This distinction is marked by the church's confession of faith in and union with Christ expressed in baptism. Hence, it affirms the presence and activity of the Spirit of God in all dimensions of human society without attempting to transform them into the church or distinctively Christian institutions. The involvement of Christians in the various dimensions of human society is to prepare for and to anticipate God's reign, but not to establish

17.For a discussion of holiness see Field (in press), Broward and Oord (2015), Richardson (2005) and Storey (2005) and on ecclesiology see Nausner (2010), Snyder (2014) and Leclerc and Maddix (2014).

18.Ethical realism is often associated with the work of Rienhold Niebuhr. For a contemporary articulation of this tradition by a Methodist theologian see Lovin (2008).

19.Jürgen Moltmann has developed a contemporary ethics of hope in Moltmann (2012). that reign. ${ }^{20}$ It is to promote societies characterised by justice, mercy and truth. Justice is treating people in accordance with who they are as persons created in the image of God and proportionate to their actions. Mercy is going beyond justice by compassionately meeting the needs and transforming the life situations of the victims, the vulnerable and the excluded. Truth is not merely words but also actions and forms of behaviour that display integrity and honesty. Promoting justice, mercy and truth entails resisting and overcoming evil, healing the wounded and empowering the disempowered. The promotion of justice, mercy and truth requires that the church engages the problem of corruption in society and the state. Corruption at its core is the denial of personal integrity inherent in the idea of truth; it results in people being treated unjustly, and contributes to the suffering of many.

A social ethic rooted in prevenient grace affirms the presence and activity of the Spirit in all people and, thus, the ethical contribution of people of all faiths and no faith. It further affirms that this contribution is rooted in their religious or non-religious traditions. It, thus, confirms the imperative of working with people of all religious beliefs, and of none, in establishing societies characterised by justice, mercy and truth whilst recognising that these values will be interpreted diversely. It affirms the necessity of genuine dialogue with those whose perspectives are rooted in divergent traditions with the hope of learning from others for it recognises that the Spirit has been at work in their traditions and, hence, that these traditions have unique and valuable insights into the meaning of mercy, justice and truth that are not present, have been lost or been suppressed within the Christian tradition. During the struggle against apartheid South Africans from diverse traditions worked together against apartheid, appealing to their resources from these traditions. In some case there was a deliberate drawing of resources from more than one tradition to develop a more enriched understanding of what justice and compassion meant. Many Christians drew on African cultural concepts, Black Consciousness or Marxist social analysis to articulate a South African Christian ethic (Boesak 1977; Mosala 1986; Villa-Vicencio 1992:196). In the contemporary context a potentially fruitful approach would be to develop this and also to engage in a mutual dialogue with Islam. Whilst it was not articulated in this way this process coheres with an ethic rooted in prevenient grace.

An ethic rooted prevenient grace affirms that God is at work in the structures and institutions of society. It, thus, provides the basis for the development of a theological interpretation of the state and its organs as called not to enforce 'law and order', nor to promote the economic prosperity of the few, nor to provide corruptly for the benefit of the political elite, but to promote justice, mercy and truth. ${ }^{21}$ The Spirit is present

20.In the Methodist tradition the being and praxis of the church in society is multidimensional (see Nausner 2010; Snyder 2014; \& Leclerc \& Maddix 2014). For the purpose of this article I am focusing on the ethical dimension.

21.This understanding is an important corrective and addition to Wesley's theology. Wesley's theological interpretation of the state focused on the question of authority and legitimate power resulting in a conservative ethic of obedience to the king as the God-established authority (see Weber 2001; and Grassow 2005). 
and active within the complex dynamics of the political processes; however, that does not mean one can identify all the products of political machinations with the work of God. Grace is always personal and, hence, responsive; whilst the Spirit is actively present this does not determine the outcome of the political process as the human players are free in their response to the presence and activity of the Spirit. Hence, the Spirit not only works with, but also despite and against the interests of the political actors. The church's engagement with the political sphere is deeply contextual; interpreting political policies and praxes on the basis of their conformity to justice, mercy and truth; engaging in prophetic critique where the state does not conform to the above, and offering critical support where it does. The church must remain a disturbing presence in any society.

An ethic rooted in prevenient grace affirms that the Spirit is at work in the unusual and the irregular. The Bible, in different places, portrays the Spirit's work as erupting in unusual, unexpected and frankly unsuitable contexts. It seems that the Spirit delights in upsetting our human perceptions of decorum, order, respectability and honour. The Spirit uses a prostitute like Rahab, a selection of really unsuitable judges like Gideon or Samson, a prophet like Jonah, a locust eating fanatic like John the Baptist, or a Roman centurion like Cornelius. Hence, in contrast, Wesley's political conservatism, such an ethic affirms that it is not only the state and its various organs that is an instrument of God in society, it is also diverse movements and people working against oppression and for justice seeking to bring healing and wholeness to human beings and the earth (see Rieger \& Pui-lan 2012). This was a lesson learned by the church in South Africa in the 1980's as some church leaders and theologians asserted that the apartheid state was illegitimate and the liberation movements were God's instruments of justice (Villa-Vicencio 1990).

An ethic rooted in prevenient grace affirms trans-cultural ethical concepts such as human rights and natural law but recognises that these emerge in diverse ways in different times, cultures and social locations. In a world that is changing, in which traditional values no longer hold sway, where society is becoming more pluralistic some Christian ethicists are searching for a place to stand, common ground upon which all can agree or an ethical foundation that can stand beyond and above the socio-cultural flux. In some cases appeals to natural law, as such a secure ethical startingpoint, are covert ways of asserting traditional morality under the guise of universal norms. In others they are genuine attempts to seek for trans-cultural norms to which people of all religions, or none, can be accountable - this is often expressed in the language of human rights (see VillaVicencio 1992:117-153; Reed 2007). In his A concise history of England from the earliest times to George the II, Wesley notes the development of civil and political rights in Britain. He describes how they arose in the context of the complexity and conflicts of history and often in contrast to and against the intensions of the major actors involved (see Wesley 1775). Yet he could also describe such rights as gifts from God that we have a duty to defend and develop. ${ }^{22}$ Hence, an ethic grounded in prevenient grace affirms both that there are trans-cultural norms which Wesley viewed as being summed up in the Golden Rule or in the triad of justice, mercy and truth; but their significance is continually being unfolded in diverse ways and contexts through diverse struggles for justice and freedom. It is consist with such an approach to expect new developments in our ethical understanding as we relate these values to new and changing contexts.

An ethic rooted in prevenient grace affirms that the Spirit is at work in the fissures and fractures of human power structures and, hence, amongst those who are vulnerable, excluded, downtrodden, exploited, oppressed and victimised to prepare for and anticipate the coming of God's reign which is proleptically present in the church and within persons. This ethic places the margins of human society at the centre of our ethical concern, causing the interpretation of ethical norms and values to be interpreted with a particular focus on their relation to the excluded, and a rejection of the perspective of those who interpret these values in the service of the economic and political elite. The affirmation that the Spirit is active amongst the marginalised is more than this; it is an affirmation of the response of the marginalised to the work of the Spirit. It, thus, affirms the agency of the marginalised and their resistance against oppressive and unjust systems.

\section{Conclusion}

The theology of prevenient grace affirms that the Spirit blows where the Spirit wills in unusual, unexpected and surprising ways and places, amongst all people, preparing for and anticipating God's reign. The ethical task is not to determine what the Spirit can or should do but rather for the church to discern the presence and purpose of the Spirit by the critical interpretation of the images and motifs from the biblical witness, and relating them to a systematic analysis of a given context in the light of the history of the church's engagement with society. The task reaches fulfilment as the church responds to the Spirit's work by participating in God's mission in the world.

\section{Acknowledgements Competing interests}

The author declares that he has no financial or personal relationships which may have inappropriately influenced him in writing this article.

\section{References}

Boesak, A.A., 1977, Farewell to innocence: A socio ethical study on black theology and power, Orbis, Maryknoll, NY.

Borgen, O.E., 1972, John Wesley and the sacraments, Gotthelf, Zürich.

Brendlinger, I.A., 2006, Social justice through the eyes of Wesley: John Wesley's theological challenge to slavery, Joshua, Ontario.

Brendlinger, I.A., 2007, To be silent ... Would be criminal: The antislavery life and writings of Anthony Benezet, Scarecrow, Lanham, MD.

Broward, J. \& Oord, J., 2015, Renovating holiness, SacraSage, Nampa, ID. 
Collins, K.J., 2007, The theology of John Wesley: Holy love and the shape of grace, Abingdon, Nashville, TN.

Crofford, J.G., 2010, Streams of mercy: Prevenient grace in the theology of John and Charles Wesley, Emeth, Lexington, KY.

De Gruchy, J.W., 1991, Liberating reformed theology: A South African contribution to an ecumenical debate, Eerdmans, Grand Rapids, MI.

Dupuis, J., 2001, Toward a theology of Christian pluralism, Orbis, Maryknoll, NY.

Field, D.N., 2003, 'On (Re)centering the margins: A Euro-African perspective on the "Option for the Poor"', in J. Rieger (ed.), Opting for the margins: Postmodernity and liberation in theology, pp. 45-69, Oxford University Press, New York, NY. $\mathrm{http}: / / \mathrm{dx}$.doi.org/10.1093/019516119X.003.0003

Field, D.N., 2015, 'Prevenient grace and universal atonement in the theology of William Burt Pope', Aldersgate Papers 11, 33-52.

Field, D.N., (in press), 'Holiness, social justice and the mission of the church: John Wesley's insights in contemporary context', forthcoming in Holiness. A Journa of Wesley House Cambridge 1(2). http://www.wesley.cam.ac.uk/holiness/

Grassow, P.S., 2005, 'Christian perfection in an imperfect world', in P. Malinga \& N Richardson (eds.), Rediscovering Wesley for Africa, pp. 87-96, Methodist Church of Southern Africa, Silverton.

Klaiber, C., 2013, Von Gottes Geist Verändert: Ursprung und Wirkung Wesleyanischer Pneumatologie, Edition Ruprecht, Göttingen.

Knitter, P.F., 2002, Introducing theologies of religion, Orbis, Maryknoll, NY.

Leclerc, D. \& Maddix, M.A. (eds.), 2014, Essential church. A Wesleyan ecclesiology, Beacon Hill, Kansas City, MO.

Lovin, R.W., 2008, Christian realism and the new realities, Cambridge University Press, Cambridge. http://dx.doi.org/10.1017/СBO9780511611520

Maddox, R.L., 1994, Responsible grace: John Wesley's practical theology, Kingswood, Nashville, TN.

Miguez Bonino, J., 1998, 'Wesley in Latin America: Theological and historical reflection', in R.L. Maddox (ed.), Rethinking Wesley's theology for contemporary Methodism, pp. 169-182, Kingswood, Nashville, TN.

Miguez Bonino, J., 2000, 'Salvation as the work of the Trinity: An attempt at a holistic understanding from a Latin American perspective', in M.D. Meeks (ed.), Trinity community and power: Mapping trajectories in Wesleyan theology, pp. 69-83, Kingswood, Nashville, TN

Moltmann, J., 2012, Ethics of hope, Fortress, Minneapolis, MN.

Mosala, I.J., 1986, 'The relevance of African traditional religions and their challenge to black theology', in I.J. Mosala \& B. Tlhagale (eds.), The unquestionable right to be free: Essays in black theology, pp. 91-100, Skotaville, Johannesburg.

Murray, R., 1992, The cosmic covenant: Biblical themes of justice, peace and the integrity of creation, Sheed and Ward, London.

Nausner, M. (ed.), 2010, Kirchlichers Leben in Methodistischer Tradition: Perspektiven aus drei Kontinenten, Edition Ruprecht, Göttingen.

Nolan, A., 1988, God in South Africa: The challenge of the gospel, David Philip, Cape Town.

Oden, T.C., 1993, The transforming power of grace, Abingdon, Nashville, TN

Park, A.S., 1993, The wounded heart of God: The Asian concept of Han and the Christian doctrine of sin, Abingdon, Nashville, TN.
Park, A.S., 2004, From hurt to healing: A theology of the wounded, Abingdon, Nashville, NT.

Pope, W.B., 1880, A compendium of Christian theology being an analytical outline of a course of theological study, biblical, dogmatic and historical, vol. 3, Wesleyan Conference Office, London.

Reed, E.D., 2007, The ethics of human rights: Contested doctrinal and moral issues, Baylor University Press, Waco, TX.

Richardson, N., 2005, 'Christian perfection in an imperfect world', in P. Malinga \& N. Richardson (eds.), Rediscovering Wesley for Africa, pp. 161-172, Methodist Church of Southern Africa, Silverton.

Rieger, J. \& Pui-lan, K., 2012, Occupy religion: Theology of the multitude, Rowman \& Littlefield, Lanham, MD.

Rodes, S.J., 2013, From faith to faith: John Wesley's covenant theology and the way of salvation, Pickwick, Eugene, OR.

Rogers, C.A., 1967, 'The concept of prevenient grace in theology of John Wesley', PhD thesis, Department of Religion, Duke University, Durham.

Runyon, T., 1998, The new creation: John Wesley's theology today, Abingdon, Nashville, TN.

Sharp, G., 1764, A representation of the injustice and dangerous tendency of tolerating slavery or of admitting the least claim of private property in the persons of men in England, Benjamin Wright/Robert Horsfield, London.

Shelton, W.B., 2014, Prevenient grace: God's provision for fallen humanity, Francis Asbury, Anderson.

Snyder, H.A., 2014, The radical Wesley: Patterns and practices of a movement maker, Seedbed, Franklin.

Storey, P., 2005, 'Why in the world would you want to be a Methodist if you're not Wesleyan?', in P. Malinga \& N. Richardson (eds.), Rediscovering Wesley for Africa, pp. 11-28, Methodist Church of Southern Africa, Silverton.

Villa-Vicencio, C., 1990, Civil disobedience and beyond: Law, religion and religion in South Africa, David Philip, Cape Town

Villa-Vicencio, C., 1992, A theology of reconstruction: Nation building and human rights, David Philip, Cape Town. http://dx.doi.org/10.1017/CBO9780511607592

Weber, T.R., 2001, Politics and the order of salvation: Transforming Wesleyan political ethics, Kingswood, Nashville, TN.

Wesley, J., 1775, A concise history of England from the earliest times to George the II in four volumes, Robert Hawkes, London.

Wesley, J., 1976, Explanatory notes upon the New Testament, Epworth, London.

Wesley, J., 1979, The works of the Rev. John Wesley, M.A., Thomas Jackson (ed.), 3rd edn., vols. 14, Baker Book House, Grand Rapids, MI.

Wesley, J., 1985, The works of John Wesley, vol. 2, Sermons II, 34-70, Abingdon Press, Nashville, TN. (Bicentennial Edition.)

Wesley, J., 1986, The works of John Wesley, vol. 3, Sermons III, 71-114, Abingdon Press, Nashville, TN. (Bicentennial Edition).

Wesley, J., 2007, Primitive physic or an easy and natural method of curing most diseases, The New Room, Bristol.

Wesley, J., 2012, The works of John Wesley, vol. 12, Doctrinal and Controversial Treatises I, Abingdon, Nashville, TN. (Bicentennial Edition).

Wesley, J., 2013, The works of John Wesley, vol. 13, Doctrinal and Controversial Treatises II, Abingdon, Nashville, TN. (Bicentennial Edition). 